\title{
Affordable telecommunications
}

\section{A new digital economy is calling}

\author{
Marta Poblet \\ RMIT University and Universitat Autonoma de Barcelona
}

\section{Summary}

The unparalleled success of mobile technologies, the emergence of new modes of software and hardware production, and the free circulation of shared knowledge in the Web 2.0 have enabled a new generation of bottom-up, community-based, costeffective telecommunications initiatives and projects. While these endeavours find their roots in previous hobbyists' movements (i.e. amateur radio, software hackers, do-it-yourself communities) today's' initiatives are able to connect, co-produce and share knowledge with world-wide communities, engaging new participants both at the local and the global level.

This article reviews recent developments that aim to provide free or low-cost access to telecommunication services in different areas. From Do-It-Yourself (DIY) satellites to mesh networks, these projects tap into the wisdom and resources of communities to offer non-commercial alternatives to present telecommunications services. The technology, organisational, and regulatory challenges they also face cannot be underestimated either. However, in their struggle to find and consolidate new markets, affordable telecommunications reveal that a new digital economy based on co-production could be under way.

\section{Introduction}

At the end of 2013, there will be almost as many mobile-cellular subscriptions as there are people on earth (6.8 and 7.1 billion respectively), and global mobile-cellular penetration will approach 100\%, mainly driven by the Asia and Pacific region, with more than half of the subscriptions (ITU 2013). The growth of cell phones over the past decade has no precedent if compared to any other information and communication technology (ICT), and in most developing countries this technology has leapfrogged landline infrastructures and fixedtelephone subscriptions. The difference between mobile-cellular penetration and Internet access is particularly striking: in the developing world, $31 \%$ of the population is online, compared with $88 \%$ of citizens having mobile subscriptions (in Africa, the figures are $16 \%$ and $63 \%$ respectively). While these data prove the uncontested success of mobile technologies as the most dynamic and fast-growing ICT market, they also reveal that ubiquitous, pervasive access to Internet in the global village is far from being achieved.

Yet, the many benefits of mobile communications are also limited by barriers related to cost, technology and access. Mobile services can be very expensive in a number of world regions: 
whereas an "entry level mobile broadband plan" represents approximately $1-2 \%$ of the gross national income (GNI) per capita in developed countries, the cost ranges from 11-25\% of GNI per capita (ITU 2013) in less developed economies. Especially in Africa, where the price of a $1 \mathrm{~GB}$ computer-based data plan represents on average more than 50\% of GNI per capita, mobile-broadband services remain largely unaffordable (ITU 2013). As regards technology hurdles, the coverage gaps between urban and rural areas persist in many countries. In some others, difficulties may derive from network congestion, power outages, etc. Finally, digital exclusion may adopt different forms: a clear gender gap in low and middle-income countries where "women are 21\% less likely than men to own a mobile phone" (GSMA 2012), lack of digital literacy in low-income communities, cultural barriers, etc. While the latter issues remain persistent societal challenges not to be underestimated, this article focuses on how a combination of market barriers, inexpensive software and hardware, cooperative effort, and "peer-produced" knowledge (Benkler 2006) has fuelled the design and implementation of affordable telecommunications. The sections that follow introduce the notion of "affordable communications" and present various schemes aiming to provide free or very affordable communications in different countries and world areas. The review concludes by pointing to some trends in how affordable telecommunications may reshape the way we design and use new tools and services.

\section{Affordable telecommunications, appropriate technologies}

Affordable telecommunications can be broadly conceived as technology solutions that are cost-effective for both individual citizens and their communities. These technology solutions typically emerge from initiatives by hobbyists and/or developers connected to different open-source communities, are initially tested and implemented in local contexts, and then scale to larger communities of both developers and final users.

The notions of "affordable communications" or "affordable technologies" are sometimes used as a synonym of "appropriate technologies", the concept that German economist Ernst Friedrich Schumacher contributed to popularising in his most influential book, Small is beautiful (Schumacher 1973). Schumacher's work gave birth to the Appropriate Technologies movement advocating for a choice in technology solutions that were user-friendly, ecologically suitable, and applicable to the scale of the community. The movement has had a long-lasting impact on policies for socioeconomic development as it was enthusiastically adopted by international agencies and governments in the 1970 s and the 1980 .

The Appropriate Technologies ecosystem of centres, programs, and organisations declined in the subsequent decades, but not without greatly influencing the contemporary policies on "sustainable development", of which it can be considered as the precursor. In a 2010 blog 
post, International Development Enterprises founder Paul Polak, who had embraced the movement at its beginning, declared the death of the appropriate technology movement, stating that "with its passing, thousands of technically effective, often outrageously expensive tools lie gathering dust on the shelf" (Polak 2010). Polak's criticism highlights why "appropriate technologies" and "affordable technologies" are not necessarily exchangeable concepts: user-centered solutions are not always affordable, very much like how low-cost outputs are not always user-friendly nor have a low-learning curve. There are innumerable examples that go in both ways. Affordability relates to lowering costs, whereas appropriateness relates to iterative design involving users at all stages of the process. The most interesting examples lie in the intersection between the two. And do-it-yourself telecommunications can be quoted as one of those.

\section{Do-it-Yourself Telecommunications}

\section{DIY Satellites}

In the first of a recent series of four tutorial books, amateur satellite maker Sandy Antunes boldly claims that "that anyone can build a satellite" (Antunes 2012). As he puts it elsewhere:

The idea is: anyone can do this. It's become now a team and an organising effort more than a technical challenge. I like that. That's what's going to commoditise space in a good way. It's like the early Internet was only connecting some government and university sites and then everyone was able to get on through various channels. I think space is going to get that way. That is how we are going to get into space. Not with massive efforts but with lots of tiny efforts. (Murphey 2012)

Antunes devotes his instructional book to "picosatellites" or "picosats", with a mass between 0.1 and $1 \mathrm{~kg}$ ( 0.22 and $2.2 \mathrm{lb}$.), and quotes the CubeSat (a 10cm $\times 10 \mathrm{~cm} \times 10 \mathrm{~cm}$ cube) as one of the immediate precursors. The CubeSat open-source standard was initially developed by California Polytechnic State University and Stanford University in 1999 to stimulate space science and exploration. ${ }^{\mathrm{i}}$ CubeSats are also used by amateur radio satellite communities, who have been launching their own satellites since the early 1960s (OSCAR-1 was launched on December 12, 1961, in the United States). In Australia, the University of New South Wales has declared its first completely undergraduate designed satellite ready for launch (AMSATUK 2013a). At present, NASA is partnering with several universities to launch CubeSats.ii 


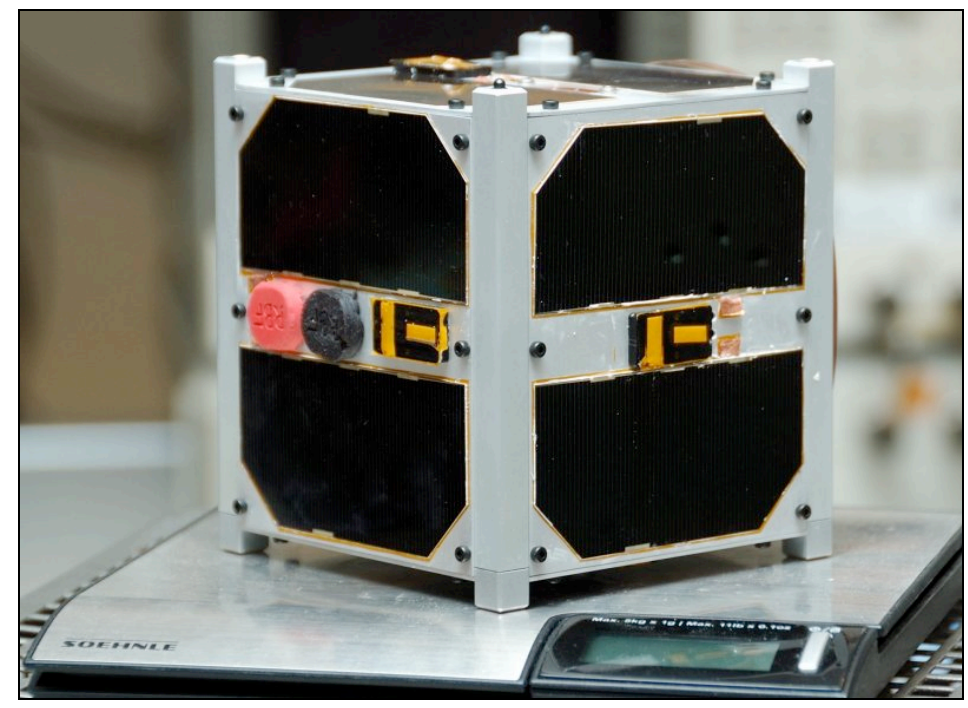

Figure 1 - CubeSat (by Erik Kulu, Public Domain)

The new generations of satellites are even more disruptive in terms of cost and skills needed. The growing availability of inexpensive, open-source hardware and software (including satellite tracking software) and off-the-shelf kits makes it possible to reduce the costs of launching a DIY satellite to a few thousand dollars (The Economist 2012). In February 2013, the first Smartphone CubeSat was launched into space carrying an amateur radio and a Google Nexus One smartphone. The team - a group of volunteers from industry and academia - aims yo demonstrate that cheap smartphone electronics can be used to control a spacecraft: "Smartphones contain highly advanced technologies and incorporate several key features that are integral to a satellite - such as cameras, radio links, accelerometers and high performance computer processors - almost everything a spacecraft needs except the solar panels and propulsion" (AMSAT-UK 2013b).

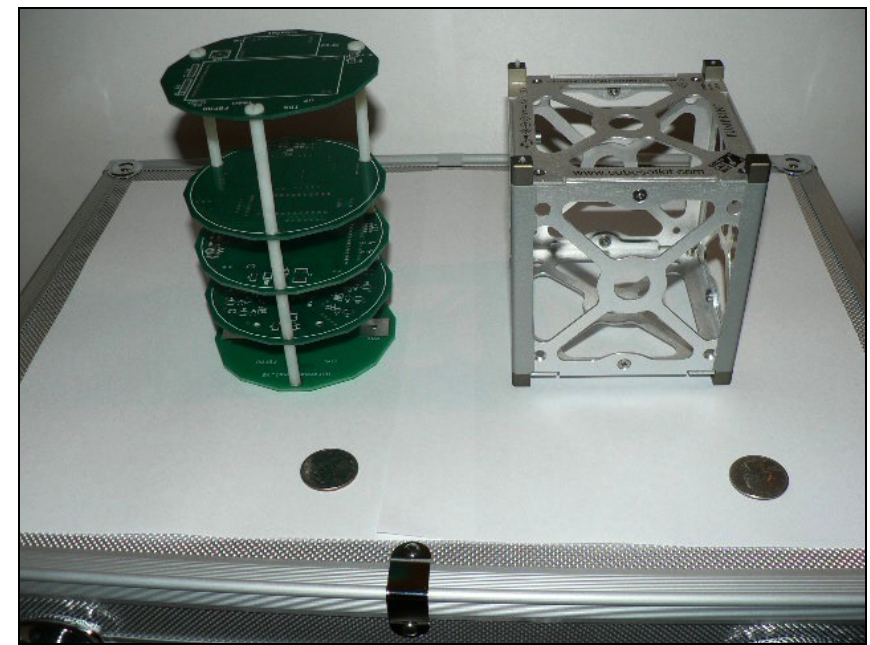

Figure 2 - Types of picosatellites (by S. Antunes, DIY Satellite Platforms 2012) 
When it comes to hobbyist expertise, the endless resources of the Web 2.0 (social media, blogs, manuals, videos, maker community forums, etc.) have considerably lowered the barriers to becoming a satellite maker. But, as Antunes forecasts, will plummeting technology costs and greater access to shared know-how effectively lead to an effective commodification of space? If so, this will certainly be a highly regulated market, for there are a number of regulatory frameworks already in place. National space agencies, the International Telecommunication Union (ITU), and the International Amateur Radio Union (IARU)) are among the organisations establishing safety standards, security checks for launch, use of spectrum, etc. In the last few years a handful of new companies have specialised in handling on behalf of their clients the vast landscape of regulatory requirements to send experiments and missions to space (Ungerleider 2012).

On a different note, it has also been also argued that one of the major risks of such a commodification of the space is an exponential multiplication of space debris: amateur picosatellites - typically positioned in low earth orbit (LEO) - have a short life span (in a few weeks or months in self-decaying orbits) and disintegrate upon re-entry to atmosphere. However, they still share the LEO region with the International Space Station (ISS) and many other science satellites. A higher probability of impacts would certainly raise new regulatory concerns and lead to a redefinition of liabilities and satellite insurances.

\section{Hardware: the New Software}

Affordable electronics are one of the core components of the "makers' revolution" that is currently transforming design and manufacturing (Anderson 2012). For some years now, low-cost, single-board computers about the size of a credit card are fostering open-source hardware hacking and bringing "computing to tinkerers and tinkerers to computing" (Hertz 2011: 6). Arduino, Raspberry Pi, and BeagleBone are the most popular pocket-size computer boards at the moment, attracting wide attention for their ability to interface and remix computers, electronic devices, sensors, etc. Arduino creators define their product as an electronics prototyping platform which is a "mash-up of open source technologies" (Banzi 2013). Raspberry Pi presents itself as a "capable little PC which can be used for many of the things that your desktop PC does". And BeagleBone markets itself as "credit-card-sized Linux computer that connects to the Internet and runs software such as Android 4.0 and Ubuntu" (Beagleboard 2013). The base prices for the three micro-boards are currently at US \$29.50, \$35, and $\$ 45$ respectively (Klosowski 2013). 


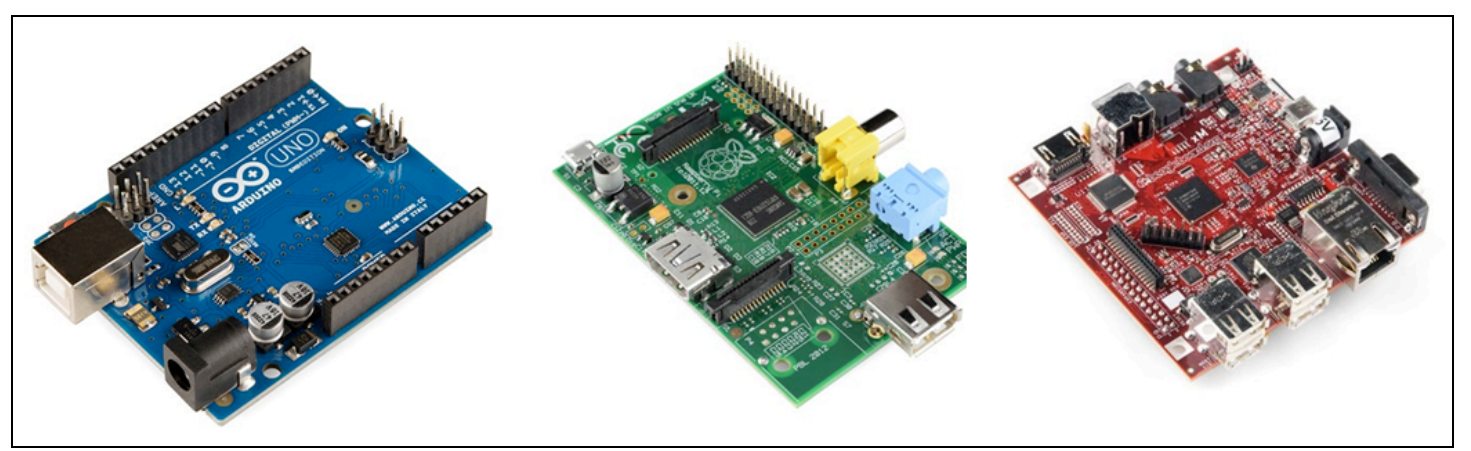

Figure 3 - Computer and controller micro-boards (remixed from Sparkfun Electronics (CC BY-NC-SA 3.0))

While there are some differences in terms of components and functionalities (Klosowski 2013, Leonard 2013) these three tiny platforms share a similar educational goal from their very inception: making electronics education more affordable. Arduino started with the basic question of "how do I make something that even a kid can use?" (Banzi 2012). The Raspberry Pi project attempted "to do something about the situation where computers had become so expensive and arcane that programming experimentation on them had to be forbidden by parents", and therefore its platform intends to be "used by kids all over the world to learn programming". ${ }^{2}$ More generally, Raspberry Pi aims "to break the paradigm where without spending hundreds of pounds on a PC, families can't use the Internet”iii. And BeagleBone is one of the outcomes of the BeagleBoard.org Foundation, a US-based non-profit corporation "existing to provide education in electronics and promotion of the design and use of opensource software and hardware in embedded computing"iv. The success of the three low-cost platforms among the hobbyist communities has largely exceed these initial goals, and these micro-boards have now become the flagship of the "makers' revolution" in electronics (Arduino and BeagleBoard products are released under Creative Commons (CC) and General Public License (GPL) licenses, while Raspberry Pi uses open source components and has released some others under a Free and Open-Source Software (FOSS) license.

A recent add to the list is BRCK developed by the Ushahidi team as a "backup generator for the Internet”. Ushahidi, initially launched as a Google maps mashup to monitor violent incidents in the aftermath of the 2007 Kenyan election, has now evolved into a full-fledged platform to monitor emergencies, disasters and crises all over the world. Many Ushahidi deployments, most of them driven by volunteers, cover areas where telecommunications infrastructures are weak, connectivity is poor, and steady power cannot be taken for granted (in many African countries, power cuts are very frequent). The BRCK is a wireless, batterypowered (up to 8 hours) modem capable of handling up to 20 devices connected at once. It can access the Internet via Ethernet, Wi-Fi, $3 \mathrm{G}$ or $4 \mathrm{G}$ cell networks, shifting between them depending on ad-hoc availability. The BRCK operates in the cloud with its own website, the BRCK cloud, to manage alerts and applications. It can also be used to monitor sensors or 
communicate with other electronic devices. ${ }^{\mathrm{v}}$ The gadget is expected to cost approximately US\$ 200, and to raise funding for its production, Ushahidi organised a crowdfunding campaign in Kickstarter (as of September 2013, the initiative had raised US $\$ 172,107$ ).

Either used as stand-alone devices or as a combination of them, the new hosts of microboards, micro-controllers, and modems are also lowering the barriers to get projects connected to cellular networks and the Internet, to make/receive voice calls and SMS messages, or to get access to Internet radio. Thus, Arduino can be turned into a mobile phone by just adding a module - a shield - that connects the microboard to the GSM network, while Raspberri Pi can be leveraged to build a private cell network (Roanhouse 2012). In addition, by connecting sensors to other objects and devices and enabling remote monitoring, they are making the Internet of Things (IoT) a tangible reality in homes, communities, and cities.

Even if many of the technologies embedded in these new devices have been there for years, the way they are currently developed, funded, produced, and distributed is different. In most cases, the initial kick-off comes from a small group of developers or small not-for-profit organisations identifying some particular need in a given context (e.g. lack of electronic literacy, poor infrastructures and connections, low budgets, etc.). The initial prototype may then be followed by a crowdfunding campaign that leverages the power of social networks to reach larger numbers of potential micro-donors. Crowdfunding campaigns also help to enlarge the community base of both developers and users, who typically play a key role in growing open source initiatives and maintaining them alive. If crowdfunding campaigns are successful in raising the pledged funds, the prototypes can then go into limited production, where the goal remains keeping the costs low for end users. And again, the communities of early adopters are the ones to share feedback and expand the know-how on the product and its potential derivatives once it has been distributed.

Hardware hacking and the new makers movement find their roots on the DIY cultures of mid-20 ${ }^{\text {th }}$ century America and the early techno-cultures of radio operation (Powell 2012). To Hertz, Make-the leading magazine of the movement-is "a revival of publications like Popular Mechanics which began at the turn of the $20^{\text {th }}$ century, fueled by a rising enthusiasm in technology" (Hertz 2011: 46). But, even if the reference publication of the makers' movement continues this path, what seems to be different from previous decades of techno-culture is that the Web 2.0 and its blogs, forums, repositories, and skype chats enable designers, developers, and user communities to connect from an early initial phase and create loose, interconnected subcommunities: crowdfunders, design makers, code sharers, end users, etc. Furthermore, these connections remain active in all stages of the cycle, providing the feedback loop that may trigger further innovation. In these processes, the 
differences between hobby and professional audiences tend to blur, since ad-hoc knowledge can at any time trigger new production processes and market opportunities, even if smallscale and niche. Similarly the distinction between "utilitarian DIY" and "hedonised DIY" (Maines 2009, Hertz 2011, Powell 2012) fades. Arduino may well be the fashionable poster child of leisure DIY, but it can also become the bridge to more accessible, participative, and smarter homes, communities, and cities.

\section{Open source GSM and community cell networks}

Over the last few years open-source cell networks have been presented as proof of concept in different hacker events (Goodin 2012) and have been deployed in music festivals like the Burning Man in Nevada or the four-day Walk of the World festival in Nijmegen (Netherlands). As Back has put it, "for most of its life GSM technology has been off-limits to open innovation, but this is rapidly changing" (Back 2012a). While many GSM standards and recommendations have been made freely accessible via standards bodies, some are restricted to GSMA members, with subscriptions starting at nearly US\$15,000 per year.

Developers have therefore concentrated their efforts in designing affordable shortcuts to building small-scale GSM networks, such as OpenBTS and OpenBSC (Back 2012b). OpenBTS is part of the GNU Radio project and is administered by the Free Software Foundation. Its ultimate goal is "a new kind of cellular network that can be installed and operated at about one tenth the cost of current technologies, but that will still be compatible with most of the handsets that are already in the market" (OpenBTS 2013). The OpenBSC aims to create "a GSM network in a box software, implementing the minimal necessary parts to build a small, self-contained GSM network" (Osmocom 2013). Both projects are part of a growing ecosystem of open-source software and hardware developments, some of them collected and curated by the Osmocom (Open Source Mobile Communication) community.

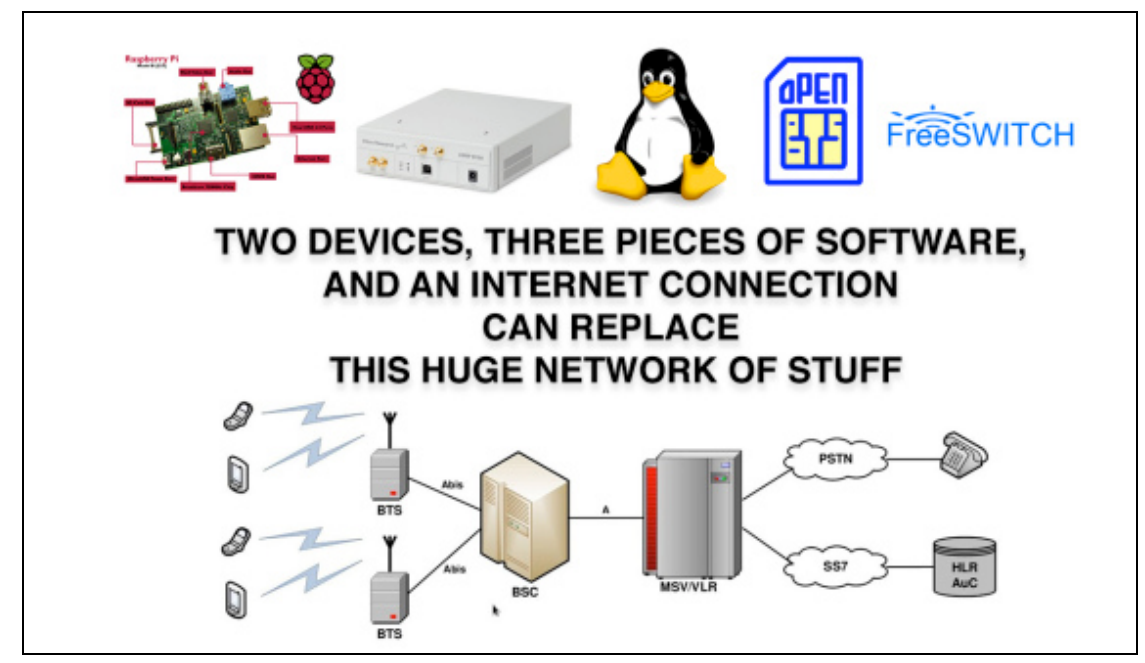

Figure 4 - A project to build an open-source GSM network (by Roanhouse (CC BY-NC-ND 3.0 US)) 
These open source solutions have also been used to provide cellular service to rural areas in different parts of the world. In Talea (Oaxaca, Mexico) the local community runs the Red Celular de Talea (the Talea Cellular Network, RCT) and the service costs 15 pesos (\$1.20) per month (Ruiz 2013). The project was supported by civil society groups and Rhizomatica, a not-for-profit whose goal is "the formation of a state-wide community telecommunications cooperative that encompasses all of the member communities with GSM networks, and provides a platform for mobilisation around regulatory issues, resource and profit-sharing, economies of scale for interconnection with existing telecommunications infrastructure (telephone and Internet), technical capacity building and maintenance" (Rhizomatica 2013). Rhizomatica is also deploying in Nigeria, where VillageTelco, another NGO in the area of affordable telecommunications, has also launched initiatives to provide free telephone services via wireless mesh networks (see section below).

In Australia, the Serval Project, founded by Paul Gardner-Stephen (Flinders University), has partnered with the New Zealand Red Cross over the last three years to develop free software "allowing mobile phones to form impromptu networks consisting only of phones" (Serval Project 2013). The Serval Project has recently completed a crowdfunding campaign to produce the "Serval Mesh Extender" a device intended "to extend range 10 to 100 times compared with Wi-Fi" (Serval Project 2013). Despite the technical challenges, the main issue that developers are facing in this case involves Google policies: "some mesh proponents say Google is unnecessarily hampering their efforts because it does not support the device-todevice mode of Wi-Fi chips in its Android software (a complaint registered with Google as “Android bug \#82”)" (Simonite 2013).

The main issues for both open-source GSM and community-run cell networks are scalability and adequate telecommunications regulatory frameworks (i.e. spectrum access, infrastructure access, licensing, etc.) but the number of initiatives launched in the last few years suggest that in many areas there is a common interest between municipal governments, community-based organisations, and commercial partners to harness the new technology developments that have lowered the barriers for co-production of cellular services.

\section{Community wireless networks}

Since the last decade, community wireless networks (CWNs) started to emerge from the grassroots to set and sustain bottom-up, non-commercial broadband networks by using inexpensive (either free or low-cost), off-the-shelf hardware and software. Most of them sprouted to fill the void of broadband connectivity in underserved urban and rural areas. To one research perspective on community networks, "the network itself is a kind of user 
protest: The dissatisfied users do not want to operate their own telecommunications networks, but they see no other way to obtain any service at all-or access to specific features" (Sandvig 2012: 135).

It is difficult to come up with a precise figure of how many WCNs have been set across the world since "some of them are highly informal and only locally known" (Braem et al. 2013: 68). According to the International Summit for Community Wireless Networks, though, these could be counted by tens of thousands (Shaffer 2013: 239), although this estimate also includes municipal broadband initiatives which may lack the bottom-up and selforganisation features of CWNs. In this line, it has been noted that "practitioners and researchers usually mix between (CWN) them and similar networks such as municipal wireless networks and commercial Wi-Fi hotspots (Abdelaal et al. 2009), which make it difficult "to collect high quality data about the transactions of all actors" (idem.). In Australia, up to 15 local CWNs have been recently listed. ${ }^{\text {vi }}$

Community networks have currently adopted a broad range of topologies (i.e. cluster, mesh, hybrid models, etc.), infrastructure (antennas, wires, fibre links, etc.), technologies, and protocols, but they all share similar principles of openness, cooperation, affordability, and neutrality. In this vein, community wireless networks have been defined as "socio-technical crucibles where community resources are shared, mobilised and reproduced" (Abdelaal and Ali 2009: 2), or as "decentralised and cooperative structures that grow organically in communities where network nodes are owned, contributed and administered by its members" (Neuman et al. 2013). Community networks have also been featured as bottomup, voluntary, collaborative, autonomous, and emergent initiatives (Gurstein 2012). From a technical standpoint, CWN are "extremely dynamic and diverse, as they are built in a decentralised manner, mixing wireless and wired links with diverse routing schemes with a diverse range of services and applications" (Braem et al. 2013: 68). CWNs typically use the deregulated 2.4 GHz band (the same of Bluetooth and cordless phones) which requires no license for broadcasters. 


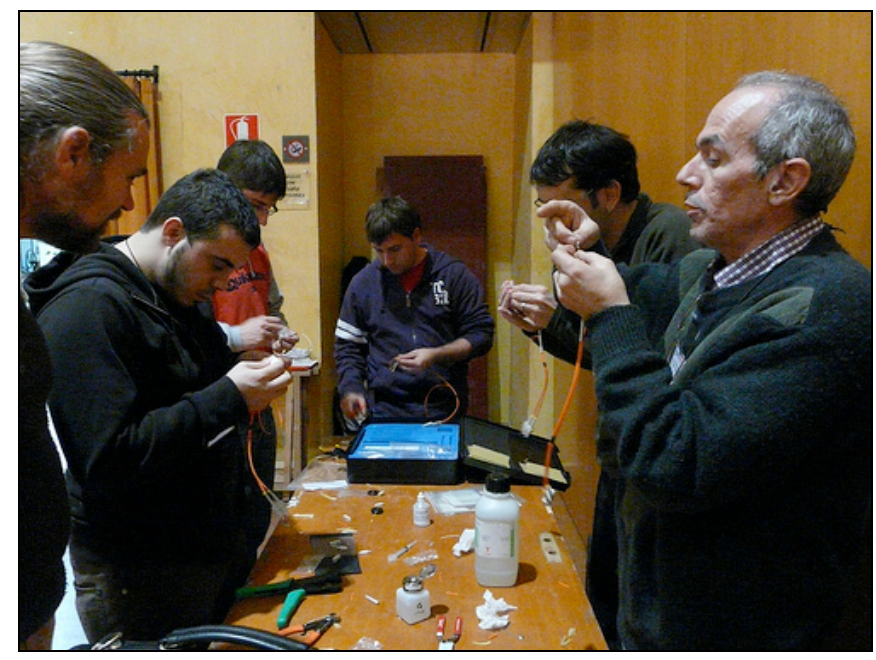

Figure 5 - Optic Fibre Workshop at Guifi.net (by Albir (CC BY-NC-SA 2.0))

\section{Guifi.net: A Case in Point}

Guifi.net, born in the small rural town of Gurb (Catalonia) in 2004, is nowadays the most extended CWN in the world, with roughly 22,000 operational nodes as of September 2013 (Guifi.net 2013). Guifi.net operates as an "open, free and neutral telecommunications network" built through "a peer to peer agreement where everyone can join the network by providing his connection, and therefore, extending the network and gaining connectivity to all." (Guifi.net 2013). In 2008, the network was legally incorporated as a foundation - the Guifi.net Foundation - and registered as an operator at the Spanish Telecommunications Market Commission (CMT) to establish formal partnerships with the public and private sectors (i.e. local municipalities, regional governments, SMEs, etc.). Guifi.net is currently extending its reach by setting new nodes in other European, American, and African countries, and is also involved in three different European $\mathrm{FP}_{7}$ research projects (Confine, Clommunity, and Commons for Europe) in partnerships with other European CWNs (i.e. FunkFeuer in Austria and AWMN in Greece), research centers, foundations, and municipal entities. The projects offer a testbed for experimental research to develop new systems and technologies. 


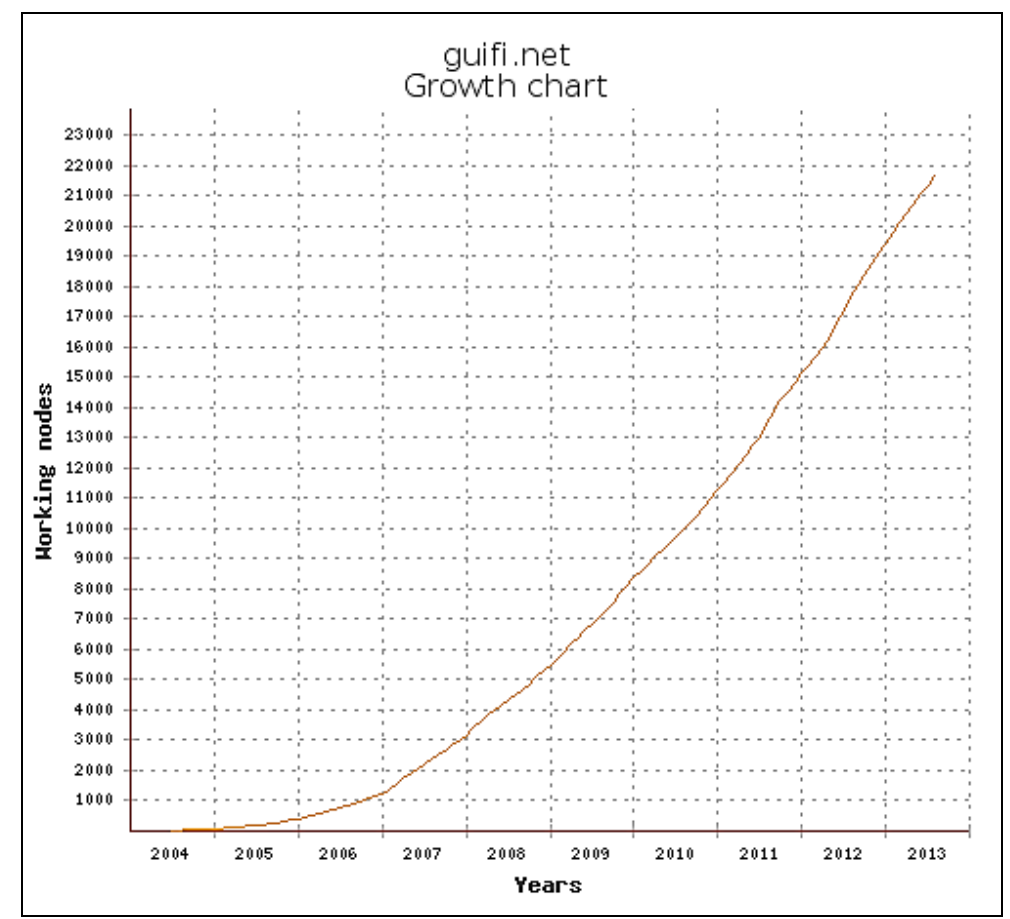

Figure 6 - Growth of Guifi.net working nodes (by Guifi.net)

The core principles of Guifi.net are embedded in its licence, also known as "The commons for an Open, Free \& Neutral Network" (OFNN commons) [“els comuns de la XOLN”], which describe the terms and conditions of free and open networks (Guifi.net 2012). The OFNN commons have been adopted by the Guifi.net membership following a deliberative process and they take stock of previous agreements (i.e. the "wireless commons" and the PicoPeering Agreement (PPA)) to update the self-regulation of key aspects of the network, such as peer-to-peer interactions, traffic, or data exchange. The OFNN commons, in addition, are conceived as "global rather than network specific", for they address issues that "any network worldwide may face in the future". vii

\section{Strengths and challenges ahead}

Guifi.net in Catalonia, Funkfeuer in Vienna, Freifunk in Berlin or AWMN in Athens, among others, are now about to celebrate their first decade since a handful of founders started to place the first antennas on building roofs. A recent study on grassroots wireless networks in Europe has found that "grassroots Wi-Fi networks mobilise human, technical, and financial resources to create sustainable alternatives to telephone and cable companies", and that successful initiatives "are forcing local incumbent ISPs to lower prices and alter terms of service agreements" (Shaffer 2013: 236). The analysis also concludes that these initiatives help to "broaden the public sphere, create opportunities for civic engagement, and transfer knowledge among community members" (Shaffer 2013). In another study reviewing the contribution of CWNs to the proliferation and affordability of broadband access in the Czech Republic, the authors state that "key success factors include obtaining a non-profit status, 
engaging academics, and cooperating with government entities" (Dulik et al. 2013: 215). In this regard, Guifi.net cofounder and president Ramon Roca insists that "public private partnerships are essential” (Roca 2010).

More generally, researchers have highlighted the role of CWNs "as venues for human capital generation" and describe "CWNs as open innovations where facets of human capital are produced, shared, brokered and/or reproduced among community members while building and maintaining such collective telecommunication infrastructures" (Aldelaal and Ali 2012: 3343). In this line, CWNs are also seen as learning-by-doing, practicing spaces that empower its members with new skills and capacities and contribute to expand the knowledge base. The Web 2.o has also contributed to enlarge the community base by linking different groups and facilitating the organisation of forums, meetings, workshops, hackathons, etc.

However, CWNs also face a number of challenges in terms of infrastructure and technology, services, governance, and regulations. As CWNs rapidly increase the number of nodes and users, the main technology issues are related with scalability, robustness, non-controlled interferences, or spectrum and channel congestion, among others. In developed countries, where the newest generations of smartphones and tablets are making wireless data traffic grow exponentially, these issues are particularly acute. The development of new technologies to allocate idle spectrum (e.g. cognitive radio) and the shared use of "white space" frequencies, increasingly available as the transition to digital TV turns analog channels off, are promising alternatives. In this line, the IEEE released its 802.22.2-2012 standard to facilitate installation and deployment of wireless regional area networks (WRANs) and enable rural cost-effective broadband wireless (IEEE 2012). However, as their predecessors, the new solutions will have to deal with a number of regulatory hurdles before broad adoption becomes possible.

When it comes to services, increasing community users' demand for new web-based applications add new challenges to CWNs. Recent research has noted that "the deployment of applications inside of community networks is surprisingly low" (Khan et al. 2013). This is the case with cloud computing services, which some researchers see "hardly existing in community networks" and therefore require an effort to integrate them as part of the CWN management tools (Pietrosemoli et al. 2013). Security, privacy, and standardisation protocols should also follow the provision of new services to address user demands' and to comply with new regulatory frameworks (e.g. the new regulation on data protection in Europe).

Both infrastructural and technology challenges are also related with governance of CWNs. As voluntary-based initiatives, CWN need also to make decisions on how to evolve as a network, how to support the volunteer base and the community at large, how to enter into 
partnerships and with whom, etc. Researchers have also reported a number of failures on the governance side. For example, analysing the case of the Chapleau network in Canada, Albert concludes that while "the project adopted a public-private partnership in which Bell Canada and Nortel Networks funded its pilot phase", it failed, among other reasons, "because of unclear and divergent goals" (Albert 2013: 178).

Further research has also proposed a distinction between "pure" and "hybrid communities" to explain possible causes for success or failure in dealing with community expectations. Thus, Camponovo et al. argue that "hybrid communities" - the ones supported by a corporation, such as Fon, which claims to be the largest Wi-Fi network in the world, with nearly 12 million hotspots as of September $2013^{\text {viii }}$ - "are better at motivating people by offering an attractive mix of incentives and support" (Camponovo et al. 2013: 113). However, to compare voluntary-based, non-commercial initiatives with company-supported networks does not address the key questions of which are the drivers for people to join and participate in CWNs, what governance structures are needed to sustain the effort, and how to deal with the potential tensions between openness, freedom, and neutrality and the broader context of telecommunications markets.

Finally, CWNs will have to adapt to regulatory changes at the national and international level. As an example, in Australia, as of 9 August 2013, the Radiocommunications Regulations 1993 have incorporated an amendment that restricts the supply of mobile phone repeaters (ACMA 2013). In Europe, the European Commission has recently issued a proposal of Regulation aiming at creating a single market for electronic communications (EC 2013). While one of the salient - and most controversial - features of the proposed reform is to eliminate roaming fees across European countries, other goals included in the proposal are to achieve greater convergence on authorisations, spectrum assignment, and consumer protection. However, it has also been noted that "there are no plans for a single telecoms regulator, which many believe is necessary for a genuine single market, or move to create a pan-European spectrum license" (Thomas 2013). The European Parliament will have the last word.

\section{Conclusion}

The initiatives on affordable telecommunications reviewed in this article can be analysed with the lens of what Benkler has defined as the "networked information economy", brought by changes that "have increased the role of nonmarket and nonproprietary production, both by individuals alone and by cooperative efforts in a wide range of loosely or tightly woven collaborations" (Benkler 2006: 2). Declining prices of computing electronics, the removal of barriers to access the production of information, and the emergence - sometimes 
spontaneous - of cooperative coproduction are among the key reasons explaining the new agile models for open source, affordable innovation by loose communities that frequently extend beyond one organisation. Very much like that the movements advocating for an open, free, and neutral Internet, the new initiatives on affordable telecommunications face enormous tensions when dealing with regulatory frameworks, markets, policies, etc. While these tensions will not easily be resolved and in many cases will require careful strategic thinking (i.e. redefining governance structures, selecting the adequate partnerships, etc.) they also hold the promise to enable further democratisation of the way we produce, share, and benefit from knowledge and services in the telecommunications domain. For sure, a new telecommunications economy is calling.

\section{Acknowledgements}

This research has been supported by two research grants from the Spanish Ministry of Economy and Competitiveness (MINECO) to the projects "CrowdCrissControl" (IPT-20120968-390000) and "Crowdsourcing: instrumentos semánticos para el desarrollo de la participación y la mediación online (DER 2012- 39492 -Co2 -01)”.

\section{References}

Abdelaal, A., Ali, H. 2009. Analyzing community contributions to the development of community wireless networks. 17th European Conference on Information Systems. [Internet]. Accessed 29 September 2013. Available from: http://www.ecis2009.it/papers/ecis2009-0709.pdf

Abdelaal, A., Ali, H. 2012. Human Capital in the Domain of Community Wireless Networks. 45th Hawaii International Conference on System Sciences. [Internet]. Accessed 29 September 2013. Available from: http://ieeexplore.ieee.org/stamp/stamp.jsp?tp=\&arnumber $=6149228$

Abdelaal, A., Ali, H., Khazanchi, D. 2009. The Role of Social Capital in the Creation of Community Wireless Networks," the 42nd Hawai'i International Conference on Systems Sciences, Waikoloa, HI U.S.A, January 5 - 8: 1-10.

ACMA. 2013. Compliance Program 2012-2013. [Internet]. Accessed 10 October 2013. Available from: http://www.acma.gov.au/Industry/Suppliers/Supplierresources/Priority-compliance-areas/priority-compliance-areas-compliance-program2012-and-2013

Albert, S. 2013. The Case of Chapleau Network: Why Community Wireless Networks Fail?. In A. Abdelaal (ed.) Social and Economic Effects of Community Wireless Networks and Infrastructures. IGI Global. September 26, 2013: 178-196. http://doi.org/10.4018/978-14666-2997-4

AMSAT-UK. 2013a. 'Australia's own BLUEsat ready for launch'. [Internet]. Accessed 20 September 2013. Available from: http://amsat-uk.org/2013/09/13/australias-bluesatready-for-launch/ 
AMSAT-UK. 2013b. 'STRaND-1 Smartphone CubeSat'. [Internet]. Accessed 2o September 2013. Available from: http://amsat-uk.org/satellites/strand-1/

Anderson, C. 2012. Makers: The New Industrial Revolution. New York: Crown Publishing Group.

Antunes, S. 2012. DIY Satellite Platforms. Sebastopol (CA): O’Reilly Media, Inc.

Back, A. 2012a. The Low Cost GSM Network is Here. DesignSpark [Internet]. Accessed 29 September 2013. Available from: http://www.designspark.com/blog/the-low-cost-gsmnetwork-is-here

Back, A. 2012b. Building a GSM network with open source. The Open H [Internet]. Accessed 29 September 2013. Available from: http://www.h-online.com/open/features/Building-aGSM-network-with-open-source-1476745.html

Banzi, M. 2012. 'How Arduino is open-sourcing imagination'. TEDGlobal June 2012, [Internet]. Accessed 24 September 2013. Available from:

http://www.ted.com/talks/massimo_banzi_how_arduino_is_open_sourcing_imaginati on.html

Beagleboard. 2013. Beaglebone. [Internet]. Accessed 24 September 2013. Available from: http://beagleboard.org/Products/BeagleBone/

Benkler, Y. 2006. The wealth of networks: how social production transforms markets and freedom. New Haven: Yale University Press.

Braem et al. 2013. Braem, B., Blondia, C., Bonicioli, J., Papathanasiou, S., Neumann, A.,Vilata i Balaguer, I., Barz, C., Rogge, H., Escrich, P., Baig Viñas, R., Tatum, B., Matson, M., Navarro, L., Freitag, F., Kaplan, A.L. 2013. A Case for Research with and on Community NetworksEditorial Note submitted to Computer Communication Review. [Internet]. Accessed 24 September 2013. Available from: http://www.sigcomm.org/sites/default/files/ccr/papers/2013/July/25000982500108.pdf

Camponovo, G., Picco-Schwendener, A., Cantoni, L. 2013. Motivations and Barriers of Participation in Community Wireless Networks: The Case of Fon. In A. Abdelaal (ed.) Social and Economic Effects of Community Wireless Networks and Infrastructures. IGI Global. September 26, 2013: 112-135. http://dx.doi.org/10.4018/978-1-4666-2997-4

Dulik, T., Bliznak, M., Jasek, R. 2013. Best Practices in Designing Low-Cost Community Wireless Networks. In A. Abdelaal (ed.) Social and Economic Effects of Community Wireless Networks and Infrastructures. IGI Global. September 26, 2013: 215-236. http://dx.doi.org/10.4018/978-1-4666-2997-4

EC. 2013. Commission adopts regulatory proposals for a Connected Continent. EU Press Releases Database. [Internet]. Accessed 24 September 2013. Available from: http://europa.eu/rapid/press-release_MEMO-13-779_en.htm

Goodin, D. 2012. At Defcon, hackers get their own private cell network: Ninja Tel. Ars Technica [Internet], http://arstechnica.com/security/2012/o7/ninja-tel-hacker-phonenetwork/

GSMA. 2012. 'Mobile and Women: An impact pathway exploring the role of mobile technology in women's empowerment'. [Internet]. Accessed 16 September 2013. Available from: https://mobiledevelopmentintelligence.com/impact_pathways/women-andmobile\#

Guifi.net. 2012. Commons for Open Free \& Neutral Network (OFNN). [Internet]. Accessed 28 September 2013. Available from: http://guifi.net/en/CommonsXOLN

Guifi.net. 2013. Operational nodes. [Internet]. Accessed 28 September 2013. Available from: http://guifi.net/en/guifi_zones 
Gurstein, M. 2012. Towards a conceptual framework for a community informatics. 2012. In A. H. Clement, M. Gurstein, G. Longford, M. Moll, L. R. Shade (eds.) Connecting Canadians: Investigations in Community Informatics. Edmonton: Athabasca University Press: $35-60$.

Hertz, G. 2011. Arduino Microcontrollers and the Queen's Hamlet: Utilitarian and Hedonized DIY Practices in Contemporary Electronic Culture (ACADIA 2011)

IEEE. 2012. IEEE 802.22 Working Group on Wireless Regional Area Networks . [Internet]. Accessed 29 September 2013. Available from: http://www.ieee802.org/22/

ITU. 2013. The World in 2013: ICT Facts and Figures. [Internet]. Accessed 29 September 2013. Available from: http://www.itu.int/en/ITU-

D/Statistics/Documents/facts/ICTFactsFigures2013.pdf

Khan, A. M., Buyuksahin, U. C., Freitag, F. 2013. Towards Incentive-Based Resource Assignment and Regulation in Clouds for Community Networks. In J. Altmann, K. Vanmechelen, and O.F. Rana (eds.): GECON 2013, LNCS 8193:197-211.

Klosowski, T. 2013. 'How to Pick the Right Electronics Board for Your DIY Project'. Lifehacker. [Internet]. Accessed 24 September 2013. Available from: http://lifehacker.com/how-to-pick-the-right-electronics-board-for-your-diy-pr742869540

Leonard 2013. How to Choose the Right Platform: Raspberry Pi or BeagleBone Black. Make. [Internet]. Accessed 24 September 2013. Available from: http://makezine.com/magazine/how-to-choose-the-right-platform-raspberry-pi-orbeaglebone-black/

Maines, R. 2009. Hedonizing technologies: paths to pleasure in hobbies and leisure. John Hopkins University.

Murphey, S. 2012. 'How to build your own personal satellite”. DIY Space Exploration [Internet]. Accessed 20 September 2013. Available from:

http://www.diyspaceexploration.com/how-to-build-your-own-personal-satellite/

Neuman, A., Navarro, L., Baig, R., Escrich, P. 2013. 'Receiver-driven routing for community mesh networks'. HotMesh 2013 Workshop at the IEEE WoWMoM Conference (Madrid/Spain). [Internet]. Accessed 26 September 2013. Available from: http://bmx6.net/news/11

OpenBTS. 2013. 'What is OpenBTS?' [Internet]. Accessed 30 September 2013. Available from: http://openbts.org/

Osmocom. 2013. 'Welcome to Osmocom OpenBSC'. [Internet]. Accessed 30 September 2013. Available from:http://openbsc.osmocom.org/trac/

Pietrosemoli, E. Freitag, F., Navarro, L., Zennaro, M., Baig, R., Astudillo Segura, A.F. 2013. 'Clommunity: A Cloud Solution for Community Networks'. [Internet]. Accessed 30 September 2013. Available from: http://2013.wirelesssummit.org/content/agenda

Polak, P. 2010. 'The Death of Appropriate Technology I: If you can't sell it don't do it.' [Internet]. Accessed 17 September 2013. Available from: http://www.paulpolak.com/thedeath-of-appropriate-technology-2/

Powell, A. 2012. Democratizing production through open source knowledge: from open software to open hardware. Media, Culture, and Society, 34 (6): 691-708. http://dx.doi.org/10.1177/0163443712449497

Rhizomatica. 2013. 'Community base station'. [Internet]. Accessed 17 September 2013. Available from: http://rhizomatica.org/projects/community-basestation/ 
Roanhouse, P. 2012. 'Proof of Concept shows how to make your own GSM phone network using \$35 Raspberry Pi’. Plan8 Media, http://www.plan8.tv/201212221050/proof-ofconcept-shows-how-to-make-your-own-gsm-phone-network-using-35-raspberry-pi/

Roca, R. 2010. 'Entrevista amb Ramon Roca'. Guifimedia. [Internet]. Accessed 28 September 2013. Available from: http://blip.tv/guifimedia/entrevista-a-ramon-roca-a-quatreparaules-3105842

Ruiz, V. 2013. 'Forgotten by telecoms, Mexico town runs cell service'. Phys.org [Internet]. Accessed 25 September 2013. Available from: http://phys.org/news/2013-o8-forgottentelecoms-mexico-town-cell.html

Sandvig, C. 2012. What are Community Networks an Example of? A Response. In: A. H. Clement, M. Gurstein, G. Longford, M. Moll, L. R. Shade (eds.) Connecting Canadians: Investigations in Community Informatics. Edmonton: Athabasca University Press: 133141.

Schumacher, F. 1973. Small Is Beautiful: A Study of Economics As If People Mattered. NY: Harper and Row.

Shaffer, G. 2013. Lessons Learned from Grassroots Wireless Networks in Europe. In A. Abdelaal (ed.) Social and Economic Effects of Community Wireless Networks and Infrastructures. IGI Global. September 26, 2013: 236-254. http://dx.doi.org/10.4018/978-1-4666-2997-4

Serval Project. 2013. What is the Serval Project? [Internet]. Accessed 14 October 2013. Available from: http://www.servalproject.org/

Simonite, T. 2013. Build Your Own Internet with Mobile Mesh Networking. MIT Technology Review. [Internet]. Accessed 14 October 2013. Available from: http://www.technologyreview.com/news/516571/build-your-own-internet-with-mobilemesh-networking/

The Economist. 2012. 'Personal Space'. [Internet]. Accessed 20 September 2013. Available from: http://www.economist.com/blogs/babbage/2012/o9/picosatellites

Thomas, D. 2013. EU regulators adopt measures to reform telecoms market. Financial Times, September 11, 2013. [Internet]. Accessed 11 October 2013. Available from: http://www.ft.com/cms/s/o/41958a7e-1aee-11e3-a605o0144feab7de.html\#axzz2i75Qcfrd

Ungerleider, N. 2012. NanoRacks is the UPS of Outer Space Shipping. Fast Company [Internet]. Accessed 20 September 2013. Available from: http://www.fastcompany.com/3000152/nanoracks-ups-outer-space-shipping

\section{Endnotes}

i See this Wikipedia entry for an updated list of university-led CubeSats and research missions: http://en.wikipedia.org/wiki/List_of_CubeSats

ii http://www.nasa.gov/offices/education/centers/kennedy/technology/elana_feature.html

iii Idem

iv http://beagleboard.org/about

${ }^{v}$ http://brck.com/ 
vi https://personaltelco.net/wiki/WirelessCommunities

vii Ramon Roca, president of the Guifi.net Foundation, in e-mail correspondence, available at https://lists.funkfeuer.at/pipermail/nodedb-interop/2010-September/oooo29.html

viii http://corp.fon.com/

Cite this article as: Poblet, Marta. 2013. 'Affordable telecommunications. A new digital economy is calling'. Australian Journal of Telecommunications and the Digital Economy 1 (1): pp.12.1 - 12.19. 